\title{
Monitoring of Hazardous Goods by Rail in the Europe: A Review
}

\author{
Michal Balog ${ }^{1}$, Lucia Knapčíková ${ }^{2 *}$ \\ \{michal.balog, lucia.knapcikova\}@tuke.sk \\ ${ }^{1}$ Technical University of Košice, Faculty of manufacturing technologies with a seat in \\ Prešov, Department of industrial engineering and informatics, Bayerova 1, 08001 Prešov, \\ Slovak Republic \\ $2^{* *}$ Technical University of Košice, Faculty of manufacturing technologies with a seat in \\ Prešov, Department of industrial engineering and informatics , Bayerova 1, 08001 Prešov, \\ Slovak Republic
}

\begin{abstract}
The use of monitoring devices is currently on a steep rise, an increase in applications that use positioning capabilities is increasing as well as a number of users. The issue of transport monitoring of hazardous goods is not unknown in Europe. Various ways that the nature of monitoring considered in determining the amount of transported hazardous goods at certain inputs and outputs were found, as it was more or less about administrative activity or statistical records.

Understanding of this issue is currently directed toward realistic tracking in cases where the exact location of the cargo is known and not an estimate that the cargo is somewhere between certain points or places.
\end{abstract}

Keywords: chemical wagons, hazardous goods, identification

\section{State of the Art}

The problem is that information about dangerous goods shipments at stations is missing in real time or in advance. Individual stations do not know how many dangerous goods are transported daily and what kind of classes of dangerous substances is involved. It is necessary to know what is being transported due to some employee readiness. [1] In the past, for example, a rail transport of chlorine has been announced in advance, which has led to certain security measures being taken. The integrated cargo management and information system promotes the commercial and business activity (Fig.1) by the rail and enables it to identify in real time all transport and shipping phenomena related to the transport of consignments. [2], [3] Key rail stations include terminals and servers that use stem and traffic data. The mission of this system is to increase the ability of rail transport competitors to compete on the transport and transport market, to create an information system with a gradual link to the neighbouring rail and to create optimal conditions for the management of rail transport, such as tracking the movement of 
wagons in national and international transport. Within the information system, the most important information about the wagon is its 12-digit number and technical parameters. Much other information related to the wagon is related to the technical and operational condition, its contents, its location in the consignments and the consignment of the consignment to the other wagons. [4], [8] Various types of events are associated with the wagon, such as wagon insertion, wagon removal, checkpoint crossing, or wagon exit on adjacent rail. New events are also introduced into the information system, which the old information system did not register. [8]

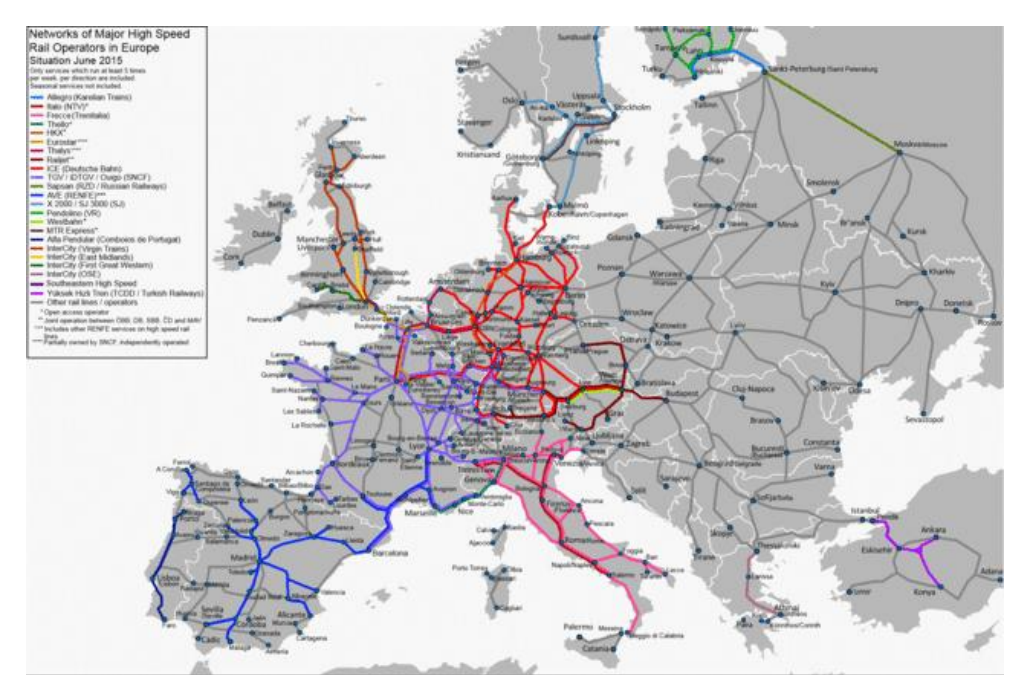

Fig. 1European rail network [8]

\section{Evidence of hazardous goods on the rail}

The designation of vehicles with a focus on rail wagons transporting of dangerous goods has certain specificities. The Figure (Fig.2) below describes a monitoring of wagons by hazardous goods transporting. 


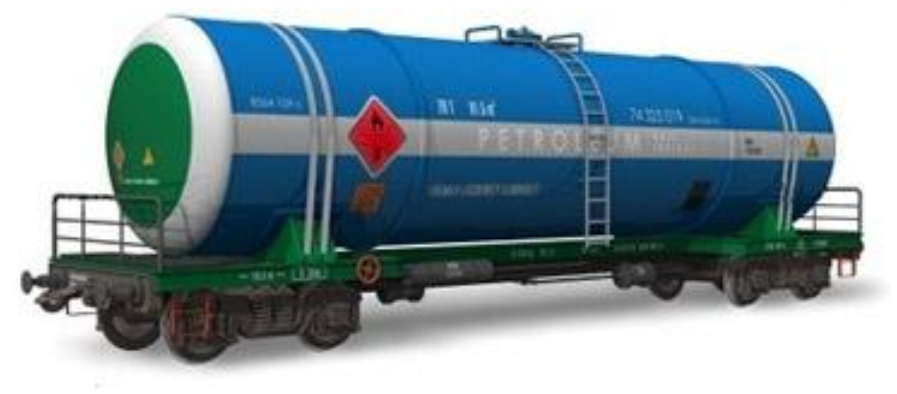

Fig. 2 Monitoring of wagons used by the hazardous goods transporting [8]

Wagons must be marked with two 400 x $300 \mathrm{~mm}$ black-and-round reflex orange squares from a certain amount of hazardous goods (in the case of a lack of attachment area they may have a size of $300 \times 120 \mathrm{~mm}$ with a frame width of $10 \mathrm{~mm}$ ). The upper part of this table shows the Kemler code and the lower figure shows the UN code. "Labeling requirements also apply to uncleaned and non-deflagrated removable or non-removable tanks, tank containers, and empty uncleaned vehicles and containers intended for the transport of bulk dangerous substances and articles." [3] The Kemler code consists of two or three digits, which in some cases is supplemented by the letter $\mathrm{X}$. The code makes it possible to quickly determine the hazard in the event of a breakdown or fire of a dangerous substance. The first digit indicates the main danger. The second and third digits indicate the side, respectively. The letter $\mathrm{X}$ before the digits indicates that the substance must not come into contact with water. If the two first digits are the same, it means an increase in the major danger. The next table describes an identification of hazardous goods according to Kemler code. [4]

Table 1. Identification of hazardous goods according to Kemler code [7]

\begin{tabular}{|c|l|}
\hline Number & \multicolumn{1}{|c|}{ Number characteristics } \\
\hline $\mathbf{1}$ & Explosive goods \\
\hline $\mathbf{2}$ & $\begin{array}{l}\text { Emission of gas due to pressure or } \\
\text { chemical reaction }\end{array}$ \\
\hline $\mathbf{3}$ & $\begin{array}{l}\text { Flammability of liquids (vapours) } \\
\text { and gases or self-heating liquid }\end{array}$ \\
\hline $\mathbf{4}$ & $\begin{array}{l}\text { Flammability of solids or self- } \\
\text { heating solid }\end{array}$ \\
\hline $\mathbf{5}$ & $\begin{array}{l}\text { Oxidizing(fire-intensifying) } \\
\text { effect }\end{array}$ \\
\hline
\end{tabular}




\begin{tabular}{|c|l|}
\hline $\mathbf{6}$ & Toxicity \\
\hline $\mathbf{7}$ & Radioactivity \\
\hline $\mathbf{8}$ & Corrosives \\
\hline $\mathbf{9}$ & $\begin{array}{l}\text { Risk of spontaneous violent } \\
\text { reaction }\end{array}$ \\
\hline
\end{tabular}

- RID International Convention on the International Carriage of Dangerous Goods by Rail (French "Règlement Concerning Transport International Ferroviaire des Marchandises Dangereuses") is an international agreement for the transport of dangerous substances by rail. Describes the classification of dangerous goods, including classification criteria and appropriate test methods, driver training requirements, requirements for the use of packaging, tanks and means of transport

- The UN code can be identified as the identification number of the hazardous substance or group of substances with similar properties, the carriage of which is subject to RID. Such substances are assigned a fourdigit code that uniquely identifies them. The UN code is one of the most commonly used systems for the rapid identification of hazardous substances. The UN code (Fig.3) is the United Nations and is therefore sometimes referred to as the UN number. This code is stated, inter alia, in the written instructions for drivers and the loading list. [8]

- HAZCHEM code is used in the UK. HAZCHEM code consists of one digit and a group of letters. The digits $(1,2,3,4)$ determine which extinguishing agent should be used. The code letter determines the method of protection against escaped dangerous substance. The presence of $\mathrm{E}$ in the HAZCHE Code recommends evacuation in the event of an accident threatened area. [7], [8] 


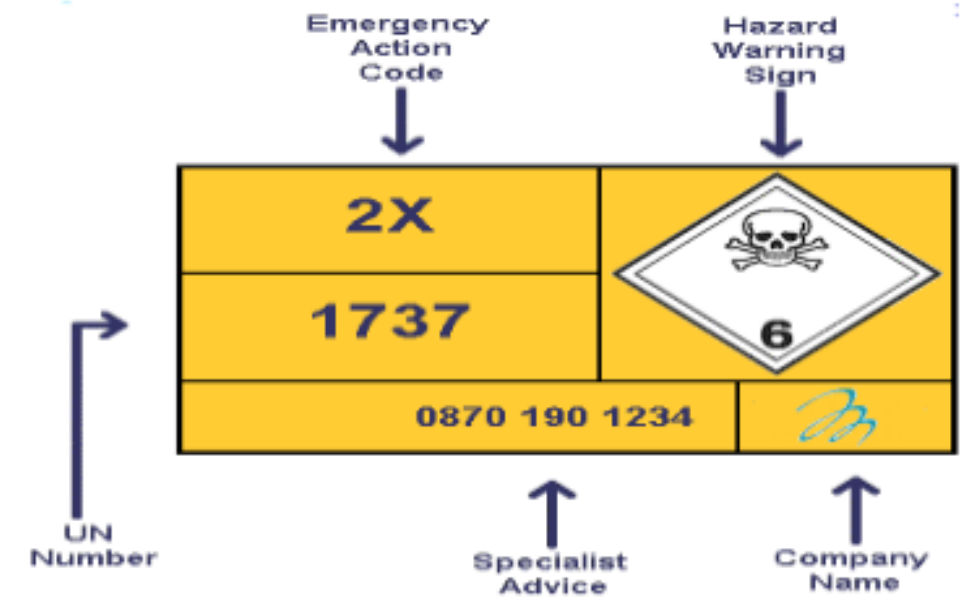

Fig. 3 Monitoring of wagons for the hazardous goods [7]

When marking hazardous substances during transport, it is also important to correctly place the warning and safety signs for which the carrier is responsible. It is necessary for fire warning boards to withstand at least 15 minutes of direct fire in order to be readable for the intervention units even at the time of their arrival at the accident site. [3], [7]

An orange orange alarm pad with the UN code and the Kemler code must always be on the wagons:

- properly fastened,

- front and rear always perpendicular to its longitudinal axis, generally on the left in the direction of travel,

- the lower edge of the warning orange panel on the front of the vehicle should not be more than 1,5 meters,

- $\quad$ provided with reflective coating [4]

In addition, tank wagons transporting compressed or liquefied gas are marked with a horizontal orange strip. [4], [8]

We can explore the risk of hazardous goods (Fig.4) shipping by various methods and methods that try to minimize or eliminate it. One way is to apply risk management. Under this term is meant a logical and systematic method of "mapping, identifying and analyzing, evaluating, handling, monitoring, and reporting risks associated with any activity, function, or process", in a way that will allow organizations to minimize losses and maximize opportunities. [5] 


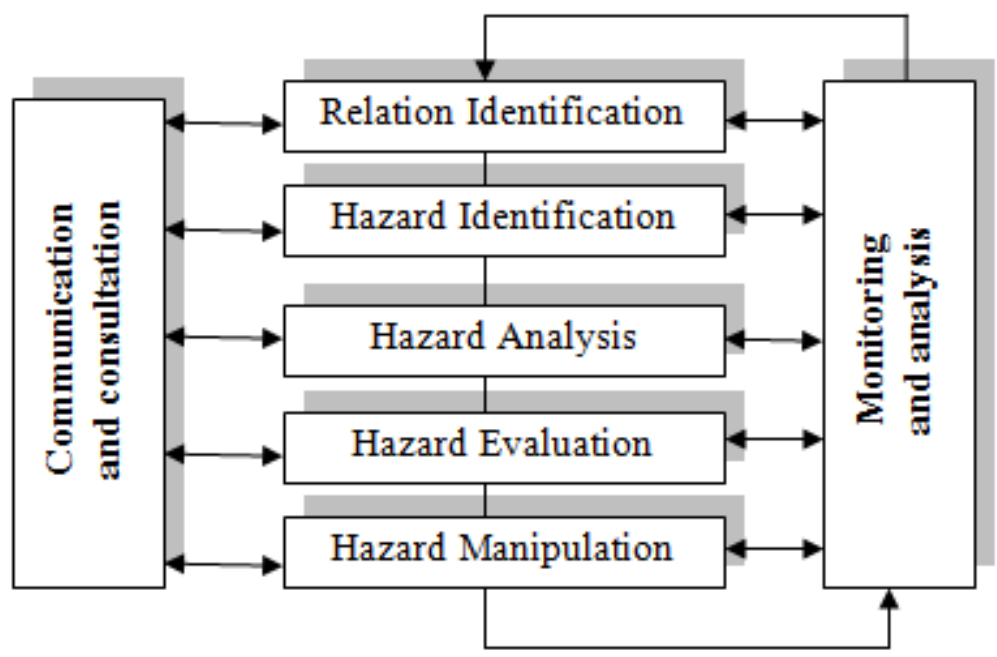

Fig.4 Evaluation of hazardous goods by rail

\section{Improving of monitoring possibilities of hazardous goods on the rail in the Europe area}

The transport of dangerous goods by rail has recently been up to date, particularly in terms of its safety. They serve the industry and consumers every day, and there is an endeavor to provide them with technical and technological innovations, but focusing on this is not enough. The following table (Table 2) describes a statistical data processing of the volume of freight rail transport that has been monitored and processed from 2006 to 2015. [7], [8] 
Table 2. Volume of freight rail transport in the Europe [8]

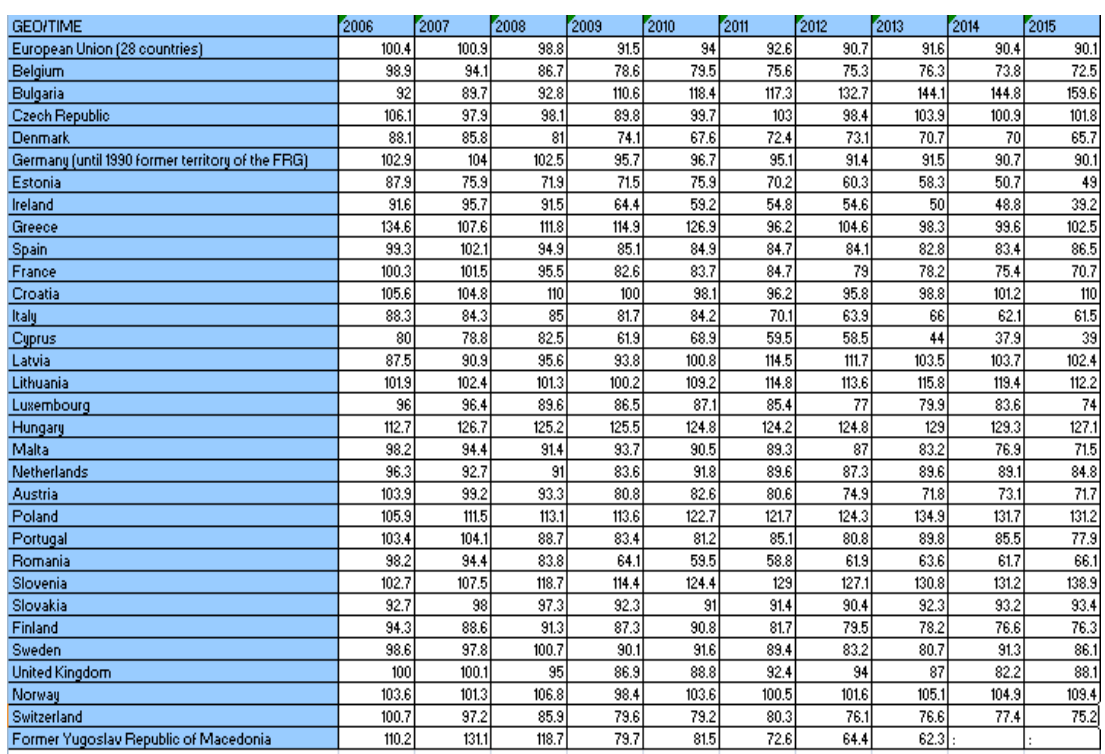

Developing implementation studies and strategic approaches in the long run also need to be addressed. As one of the few countries, Finland has set up a comprehensive strategic plan for the transport of hazardous costs for the period up to 2015, which deals not only with the state but also with the challenges and new trends that are useful as a source of inspiration for other countries, including Slovakia. In this country, there is a particular unit. [6] The institutions are responsible for this hazardous goods transport strategy and also responsible for preparing the necessary legal framework. It focuses on improving and developing supervision and management, education and services. Today's social, functional logistics chain is a basic requirement for the profitability of growing industrial sectors. Therefore, successful transport is considered to be based on the current market demand, which requires cooperation through the administrative sector. [7], [8] According to Eurostat data, the collection presented on the graph below, is based on the Regulation (EC) 91/2003 of the European Parliament and of the Council of 16 December 2002 on Rail transport statistics. Data displayed in this table cover the Rail transport of goods which relate Rail goods transport in the Member States on its national territory. [8] Member States may exclude railway undertakings which operate entirely or mainly within industrial and similar installations, including harbours. They are not covered in these statistics (Fig.5). 


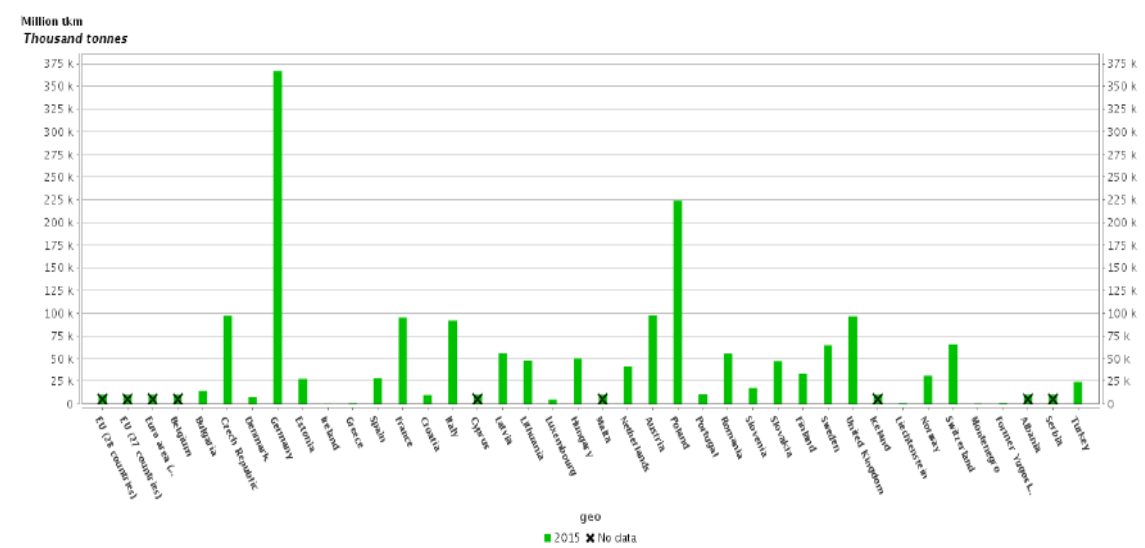

Fig. 5 Goods transport by rail in the Europe [8]

Monitoring of dangerous goods transported by rail can be accessed from the point of view:

- $\quad$ safety, which has a first share in all activities related to the transport of dangerous goods. Emphasis is placed on prevention, training, education and carefully focused information.

- it is important that the transport of dangerous goods is feasible in the business sector. In order to ensure transport as profitable and logistically efficient, emphasis is put on the quality and conditions of infrastructure, also on transport safety and on careful management and supervision.

\section{Conclusion}

The issue of the safety rail transport of dangerous substances is also very current at present, since extraordinary events associated with the escape of a dangerous substance can have disastrous consequences not only for human lives and property, but also for the environment. The constantly growing needs of society bring with it the development of industry, new technologies and the use of new kinds of dangerous substances. Among the most risky sectors and in connection with the escape of dangerous substances are the chemical industries. Each shipment of a dangerous substance brings with it a certain risk of an extraordinary event. The impact of the crash is similar to the long-term environmental burden of industrial activity, with the exception that a crash can occur relatively quickly to irreversible changes or the destruction of people's lives. 


\section{Acknowledgement}

This paper is part of a project that has received funding from the European Union's Horizon 2020 research and innovation programme under grant agreement No. 723274.

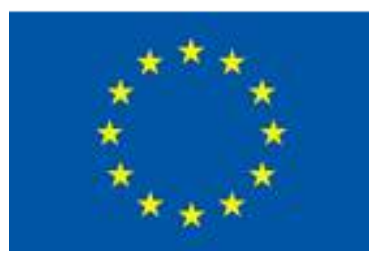

\section{References}

[1] Gnap, J. a kol., 2010. Rozvoj železničnej prepravy chemických látok na Slovensku vo väzbe na susedné krajiny a pripravované terminály kombinovanej dopravy, Žilinská univerzita v Žiline, Fakulta prevádzky a ekonomiky dopravy a spojov. (in slovak)

[2] Poriadok pre medzinárodnú železničnú prepravu nebezpečného tovaru (RID), 2003, Ministerstvo dopravy, pôšt a telekomunikácií SR.(in slovak)

[3] Janásek, D., Potoček, T., Svetlík, J., 2004. Nebezpečné látky. Žilina: Žilinská univerzita v Žiline. 123 s. ISBN 80 -8070 -243 -8. (in slovak)

[4] Babin, M., Fazakáš, M., 2011, Železničná doprava a logistika. Modelový prípad prepravy nebezpečných vecí a právna úprava. (in slovak)

[5] Sekisui chemical.com. [online], Cited [20.02.2016] Available on WWW $<$ www. Sekisui chemical.com>.

[6] Balog, M. et al. Automation monitoring of railway transit by using RFID technology, Acta Tecnologia, Vol.1, No.1, p.9-12, ISSN 2453-675X

[7]Recognition of hazardous goods. Available on <http://europa.eu/rapid/pressrelease_IP-09-1167_en.htm>

[8] Goods transport by rail

$<$ http://ec.europa.eu/eurostat/tgm/graph.do?pcode=ttr00006\&language=en> 